УДК 614.253.52:616-082

DOI 10.11603/bmbr.2706-6290.2021.2.12118

Я. В. Коморна ${ }^{1}$, I. Я. Криницька ${ }^{2}$ Н. В. Гецько², Н. В. Дужич³ , М. I. Марущак ${ }^{2}$

Комунальне некомериійне підприємство Броварської міської ради «Броварський міський центр первинної медико-санітарної допомоги» ${ }^{1}$

Тернопільський національний медичний університет імені І. Я. Горбачевського МОЗ Украӥни КЗВО «Волинський медичний інститут» ${ }^{3}$

\title{
ВИВЧЕННЯ ДУМКИ ПАЦІЄНТІВ ПРО УПРОВАДЖЕННЯ НОВИХ СЕСТРИНСЬКИХ ТЕХНОЛОГІЙ У ЦЕНТРАХ ПЕРВИННОЇ МЕДИКО- САНІТАРНОЇ ДОПОМОГИ
}

\begin{abstract}
Вивчення думки пацієнтів про упровадження нових сестринських технологій у центрах первинної медико-санітарної допомоги

Я. В. Коморна ${ }^{1}$, І. Я. Криницька², Н. В. Гецько ${ }^{2}$, Н. В. Дужич ${ }^{3}$, М. I. Марущак ${ }^{2}$

Комунальне некомерційне підприємство Броварської міської ради «Броварський міський центр первинної медико-санітарної допомоги» ${ }^{1}$

Тернопільський національний медичний університет імені І. Я. Горбачевського МОЗ України ${ }^{2}$

КЗВО «Волинський медичний інститут»
\end{abstract}

Резюме. Розширення меж сестринської практики у центрах первинної медико-санітарної допомоги (ПМсД) може сприяти підвищенню доступності та поліпшенню якості медичної допомоги населенню, регулюванню навантаження лікаря, зростанню профресійного статусу медичних сестер, підвищенню відповідальності за пацієнта.

Мета дослідження - проаналізувати думку пацієнтів про упровадження нових сестринських технологій у центрі первинної медико-санітарної допомоги (ПМСД).

Матеріали і методи. Проведено анкетування 100 пацієнтів, які отримували первинну медико-санітарну допомогу в Комунальному некомерційному підприємстві Броварської міської ради «Броварський міський чентр ПМСД». Основними параметрами дослідження були задоволення респондентів роботою реєстратури, джерела отримання інфрормації про профрілактичні огляди, перелік маніпулячій, які проводять медичні сестри загальної практики, можливість довірити медичній сестрі свої проблеми, пов'язані зі здоров'ям, стосунками в сім'ї, з дітьми, близькими родичами, вплив особистих та профресійних якостей медичної сестри на ефективність лікування та можливість упровадження самостійного прийому медичних сестер у центрах ПМсД.

Результати. Встановлено, що лише 30,0\% респондентів отримують інформацію про профрілактичні огляди від медичної сестри. На питання: «Чи були у Вас випадки, коли медсестра могла вирішити Вашу проблему без жодних консультацій з лікарем?» позитивно відповіли 60,0 \% респондентів. Щодо тих чи інших маніпуляцій, які проводять медичні сестри загальної практики, були
Study of patients' opinions about the introduction of new nursing technologies in primary medical and sanitary care centers

Ya. V. Komorna ${ }^{1}$, I. Ya. Krynytska², N. V. Hetsko², N. V. Duzhych ${ }^{3}$, M. I. Marushchak ${ }^{2}$

Communal non-profit enterprise of Brovary Town Council "Brovary Town Center of Primary Health Care"1

I. Horbachevsky Ternopil National Medical University ${ }^{2}$ Volyn Medical Institute ${ }^{3}$

e-mail: komornayyana@gmail.com

Summary. Expanding the boundaries of nursing practice in primary health care centers (PHCC) can help increase the availability and improve the quality of medical care, regulate the workload of doctors, increase the professional status of nurses, increase patient responsibility.

The aim of the study - to conduct a survey of patients' opinions on the introduction of new nursing technologies in PHCC.

Materials and Methods. A survey of 100 patients who received primary health care in Municipal Non-profit Enterprise of Brovary Town Council "Brovary Town Center of Primary Health Care" was conducted. The main parameters of the study were respondents' satisfaction with the work of the registry, sources of information on preventive examinations, a list of manipulations performed by nurses of general practice, the ability to entrust the nurse with their health problems, family relationships, children, close relatives, the influence of personal and professional qualities of the nurse on the effectiveness of treatment and the possibility of introducing independent reception of nurses in PHCC.

Results. It was found that only $30.0 \%$ of respondents receive information about preventive examinations from a nurse. To the question: "Have you had cases when a nurse could solve your problem without any consultation with a doctor?" $60.0 \%$ of respondents answered positively. Regarding certain manipulations performed by general practitioners, the following answers were received: measurement of blood pressure, heart rate $-70.0 \%$, mea- 
отримані такі відповіді: вимірювання артеріального тиску, пульсу - 70,0 \%, вимірювання зросту, маси тіла 48,0\%, реєстрація електрокардіограми -24,0\%, проведення щеплення - 25,0 \%, виписка рецептів, направлень - 45,0 \%, обслуговування вдома - 28,0 \%, обслуговування по телесрону - 26,0 \%, ін'єкції - 50,0 \%, вимірювання рівня цукру в крові - 14,0 \%, допомога психологічного характеру - 25,0 \%. Серед фракторів, що впливають на ефрективність лікування, рівень профресійної підготовки медичної сестри обрали 45,0 \% респондентів, людські якості медичної сестри - 36,0 \%, практичний досвід медичної сестри - 35,0%, партнерська взаємодія пацієнта та медичної сестри - 25,0 \%, умови догляду - 25,0 \%. Хоча на запитання: «Чи можете Ви довірити медсестрі свої проблеми, пов'язані зі здоров'ям, стосунками в сім'ї, з дітьми, близькими родичами і т. д.?» позитивно відповіли лише 45,0 \% учасників дослідження, $58 \%$ респондентів згідні на упровадження самостійного прийому медичних сестер у центрах ПМсД.

Висновки. На думку пацієнтів, медична сестра загальної практики - це рівноправний учасник поряд із сімейним лікарем усіх видів лікувально-профрілактичної роботи в центрі первинної медико-санітарної допомоги.

Ключові слова: пацієнти; медична сестра загальної практики; інновації.

\section{ВСТУП}

Медична сестра є важливим важелем, який фрормує здоров'я населення, впливає на перебіг захворювань, відновлює стан здоров'я людини, пропагує здоровий спосіб життя, долучається до розробки заходів, спрямованих на фрактори, що можуть негативно позначитись на здоров'ї, забезпечивши тим самим попередження і зниження захворюваності, поліпшення спадковості, гармонійний розвиток населення України. Особливо це стосується роботи середнього медичного персоналу центрів первинної медико-санітарної допомоги (ПМСД) [1-5].

Розширення меж сестринської практики може сприяти підвищенню доступності та поліпшенню якості медичної допомоги населенню, регулюванню навантаження лікаря, зростанню професійного статусу медичних сестер, підвищенню відповідальності за пацієнта. Досягнення в цій сорері можливі лише за допомогою подальшого інтенсивного розвитку інновацій у сестринському процесі [6, 7].

Метою дослідження було проаналізувати думку пацієнтів про упровадження нових сестринських технологій у центрі первинної медико-санітарної допомоги (ПМСД).

\section{МАТЕРІАЛИ I МЕТОДИ}

Для з'ясування думки населення про упровадження нових сестринських технологій ми провели анкетування 100 пацієнтів, які отримували первинну медикосанітарну допомогу в Комунальному некомерційному підприємстві Броварської міської ради «Броварський surement of height, body weight $-48.0 \%$, registration of electrocardiogram - $24.0 \%$, vaccination $-25.0 \%$, prescription, referrals - $45.0 \%$, home care $-28.0 \%$, telephone service - $26.0 \%$, injections - $50.0 \%$, blood sugar measurement - $14.0 \%$, psychological assistance $-25.0 \%$. Among the factors influencing the effectiveness of treatment, the level of professional training of a nurse was chosen by $45.0 \%$ of respondents, human qualities of a nurse $-36.0 \%$, practical experience of a nurse $-35.0 \%$, partnership between a patient and a nurse $-25.0 \%$, care conditions $-25.0 \%$. Although the question "Can you trust the nurse with your health problems, family relationships, children, close relatives, etc.?" only $45.0 \%$ of the survey participants answered positively, $58 \%$ of respondents agree to the introduction of self-administration of nurses in PHCC.

Conclusions. According to patients' opinions, a nurse is an equal participant, along with a family doctor, in all types of treatment and prevention work in the primary health care center.

Key words: patients; general practice nurse; innovations.

міський центр первинної медико-санітарної допомоги», створеному рішенням Броварської міської ради Київської області від 07.07.2013 р. № 972-36-06, який розпочав свою роботу з 01.01.2014 р. Основною метою діяльності Центру є забезпечення організації кваліфікованої первинної лікувально-профрілактичної допомоги населенню міста Бровари, проведення комплексу профрілактичних заходів із попередження і зниження захворюваності, інвалідності й смертності, раннього виявлення захворювань, надання прикріпленому за сімейно-територіальним принципом населенню кваліфрікованої первинної лікувальнопросрілактичної допомоги, здійснення його диспансеризації та моніторингу за станом здоров'я, забезпечення дотримання прав і обов'язків пацієнтів.

Основними параметрами дослідження були задоволення респондентів роботою реєстратури, джерела отримання інфрормації про профрілактичні огляди, перелік маніпуляцій, які проводять медичні сестри загальної практики, можливість довірити медичній сестрі свої проблеми, пов'язані зі здоров'ям, стосунками в сім'ї, з дітьми, близькими родичами, вплив особистих та профресійних якостей медичної сестри на ефективність лікування та можливість упровадження самостійного прийому медичних сестер у центрах ПМСД.

Статистичну обробку одержаних результатів проводили за загальновідомими методами.

\section{РЕЗУЛЬТАТИ Й ОБГОВОРЕННЯ}

За віком усіх респондентів поділили на 4 категоpiï: 18-30 - 15,0 \%; 31-45 - 21,0 \%; 46-60 - 29,0 \%;
Вісник медичних і біологічних досліджень Bulletin of Medical and Biological Research
2(8),2021 
61 і старше - 35,0 \%. За статтю серед опитаних чоловіків виявилося 43,0 \%, жінок - 57,0\%. За сімейним станом респондентів поділили на наступні категорії: одружений/заміжня - 60,0 \%, розлучений/розлучена - 15,0 \%, неодружений/незаміжня - 25,0 \%. За соціальним статусом учасників дослідження поділили на наступні категорії: особи, які працюють, склали 50,0 \%, пенсіонери за віком - 31,0 \%, інваліди - 9,0 \%, студенти - 11,0 \%, тимчасово не працюють - 8,0 \%.

За рівнем матеріального доходу респондентів поділили на наступні категорії: «не вистачає навіть на харчування» - 12,0 \%, «грошей досить, щоб купити їжу, але не новий одяг» - 20,0 \%, «грошей досить для купівлі їжі та одягу» - 45,0 \%, «грошей досить для купівлі більш дорогих товарів» - 15,0 \%, не знали, що відповісти - 8,0 \%.

Реєстратура $є$ основним структурним підрозділом 3 організації прийому пацієнтів у центрі ПМСД. Реєстратура регулює потік відвідувачів, інфрормує про час роботи лікарів і допоміжних діагностичних кабінетів. Від організації роботи реєстратури залежить значною мірою ритмічність роботи усіх підрозділів центру ПМСД, забезпечення найбільш оптимального розподілу потоків пацієнтів, зменшення витрат часу пацієнтів на відвідування поліклініки. Тому один із пунктів опитувальника стосувався задоволення респондентів роботою реєстратури. Частка респондентів, які задоволені роботою реєстратури, становила - 70,0 \%; частка незадоволених - 30,0 \%. Важливим елементом роботи реєстратури є запис пацієнтів на прийом до лікаря. Ми запитали в учасників дослідження, яким чином вони записувалися на прийом до лікаря. Були отримані такі відповіді: по телефрону - 25,0 \%; при особистому зверненні в реєстратуру - 50,0 \%; через лікуючого лікаря - 15,0 \%; через Інтернет - 3,0 \%; через медичну сестру - 7,0 \%.

шід сімейного лікаря
в від знайомого лікаря
в від друзів
від родичів
з інтернету
вінше
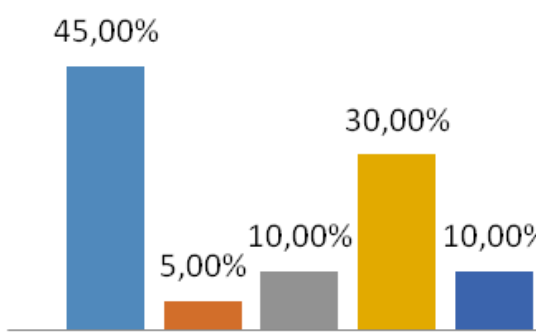

Одним із важливих аспектів інноваційних медикосоціальних технологій у сестринській справі на рівні первинної ланки охорони здоров'я $€$ навчання населення основним питанням здорового способу життя. Середній медичний персонал повинен старатися встановити довірчі відносини з пацієнтом і домагатися, щоб пацієнти були активними учасниками планування і збереження свого здорового життя.

Один із пунктів нашого опитувальника стосувався джерела отримання інорормації про профрілактичні огляди, при цьому респонденти мали можливість вибрати декілька варіантів відповіді. Ми отримали такі варіанти відповідей: від сімейного лікаря 45,0 \%; від лікаря іншої спеціальності - 5,0 \%; від знайомого лікаря - 10,0 \%; від медичної сестри 30,0 \%; від друзів - 10,0 \%; від сусідів - 5,0 \%; від родичів - 9,0 \%; із ЗМІ - 7,0 \%; 3 Інтернету - 8,0\%; 3 плакатів, листівок, брошур -4,0\%; інше-1,5\% (рис. 1).

В умовах реформування системи охорони здоров'я медичний персонал, а конкретніше медичні сестри, є одним із ключових показників надання лікувально-профрілактичної допомоги та хорошої діяльності поліклінічного закладу [8]. Середній медичний персонал, який володіє новими сестринськими технологіями, може приймати самостійні рішення, звільняючи лікаря від зайвих консультацій, викликів додому до пацієнтів із хронічними захворюваннями, тобто вивільняє час лікаря на прийом пацієнтів, яким дійсно потрібна саме його консультація. На питання: «Чи були у Вас випадки, коли медсестра могла вирішити Вашу проблему без жодних консультацій з лікарем?» позитивно відповіли 60,0 \% респондентів, негативно - 37,0 \%, інше відзначили - 3,0 \% опитаних.

Медична сестра ПМСД має виконувати усі етапи сестринського процесу, своєчасно і якісно виконувати профрілактичні та лікувально-діагностичні процедури, вводити лікарські препарати, виписувати ре-

\author{
в від лікаря іншої спеціальності \\ від медичної сестри \\ - від сусідів \\ iз $3 \mathrm{Ml}$ \\ з плакатів, листівок, брошур
}

Рис. 1. Джерела отримання інформації про профрілактичні огляди. 
цепти на лікарські засоби за призначенням лікаря, здійснювати патронаж вдома, проводити вимірювання артеріального тиску, проводити антропометричні вимірювання, підрахунок пульсу, числа дихальних рухів, надавати долікарську допомогу пацієнту.

Наступне питання нашої анкети стосувалося тих чи інших маніпуляцій, які проводить середні медичні працівники. При цьому респонденти обирали кілька варіантів відповіді. Були отримані такі відповіді. Вимірювання артеріального тиску, пульсу 70,0 \%, вимірювання зросту, маси тіла - 48,0 \%, реєстрація електрокардіограми (ЕКГ) - 24,0 \%, проведення щеплення - 25,0 \%, виписка рецептів, направлень - 45,0 \%, обслуговування вдома - 28,0 $\%$, обслуговування по телефону - 26,0 \%, ін'єкції - 50,0 \%, вимірювання рівня цукру, рівня холестеролу в крові - 14,0 \%, допомога психологічного характеру (бесіда, роз'яснення) - 25,0% (рис. 2).
На питання: «Чи можете Ви довірити медсестрі свої проблеми, пов'язані зі здоров'ям, стосунками в сім'ї, з дітьми, близькими родичами і т. д. ?» були отримані такі відповіді: так - 45,0 \%, ні - 50,0 \%, не знаю, що відповісти, - 5,0 \%.

Наступне питання нашого опитувальника стосувалося впливу тих чи інших фракторів на ефективність лікування. У категорії «абсолютно згодний» серед фракторів, що впливають на ефрективність лікування, рівень професійної підготовки медичної сестри обрали 45,0 \% респондентів, людські якості медичної сестри - 36,0 \%, практичний досвід медичної сестри - 35,0 \%, партнерська взаємодія пацієнта та медичної сестри - 25,0 \%, умови догляду - 25,0 \% (рис. 3).

Ми запитали учасників дослідження, чи згодні вони на упровадження самостійного прийому медичних сестер у центрах ПМСД. Були отримані такі відповіді: так - 58,0 \%, ні - 42,0 \% (рис. 4).

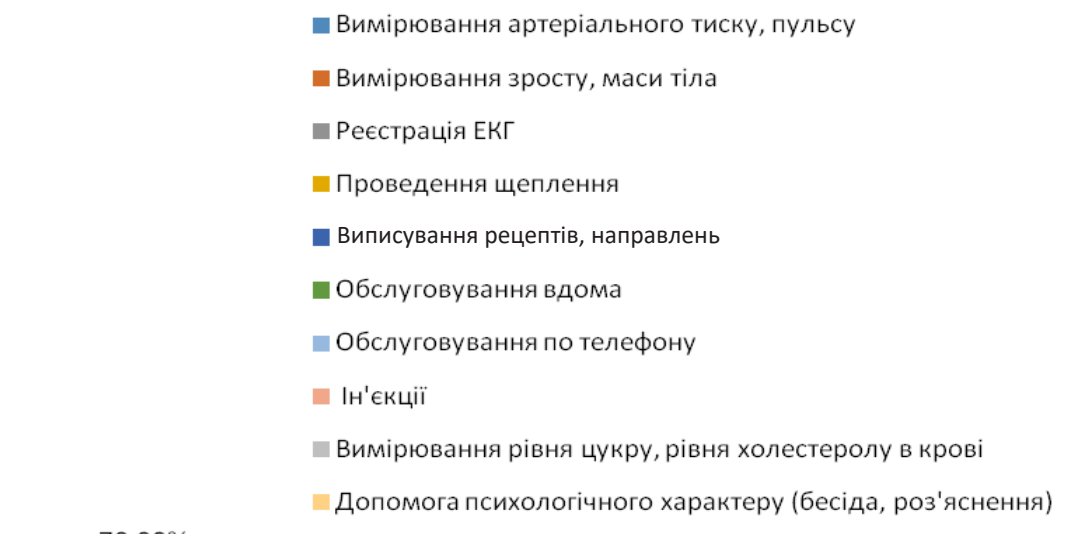

$70,00 \%$

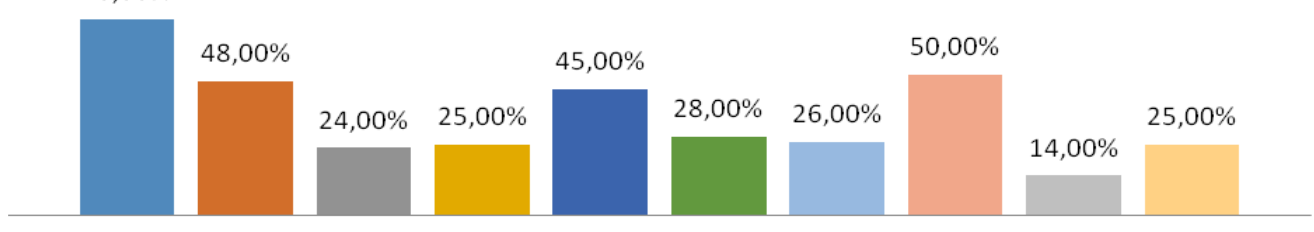

Рис. 2. Маніпуляції, які виконує медична сестра загальної практики.

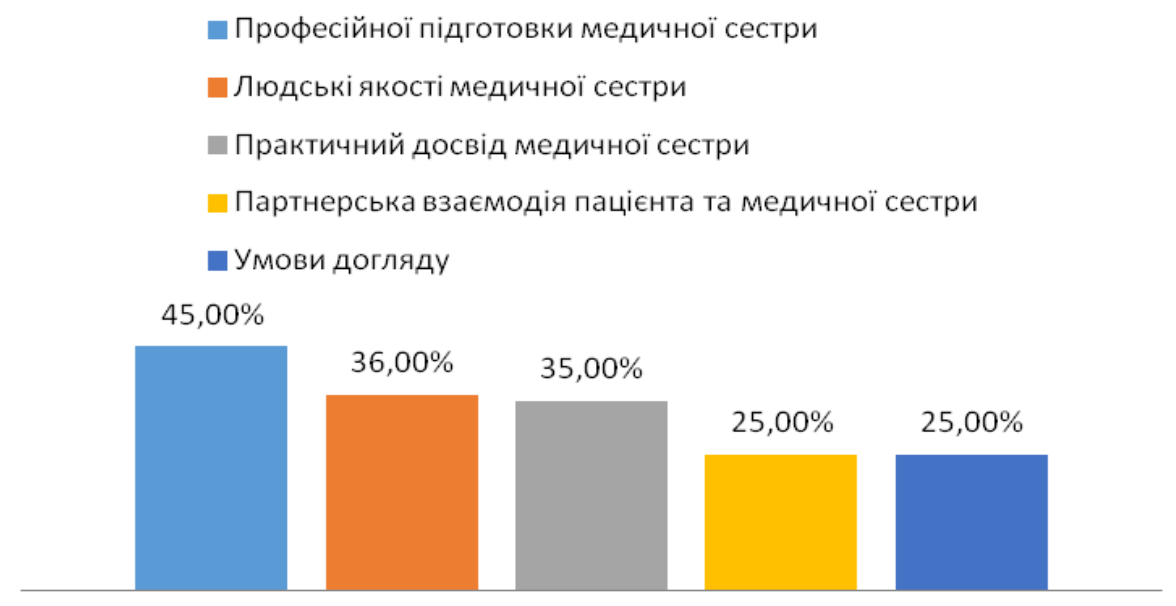

Рис. 3. Фактори, які на думку респондентів, впливають на ефективність лікування.

ISSN 2706-6282(print)

ISSN 2706-6290(online) 


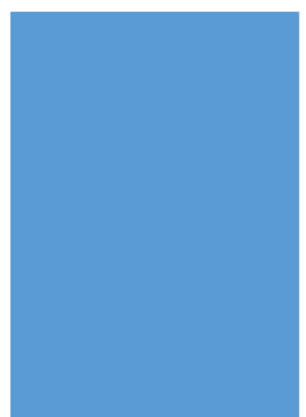

Рис. 4. Думка пацієнтів щодо упровадження самостійного прийому медичних сестер у центрах первинної медико-санітарної допомоги.

Система сучасної медицини зумовлює перегляд надання спектра комплексу діагностичних, лікувальних, реабілітаційних послуг, створення умов для упровадження нових інноваційних технологій, які стають необхідним компонентом і найбільш вірогідним методом дій надання медичної допомоги. Трансорормація традиційних моделей надання медичних послуг служби первинної медико-санітарної допомоги вимагає здійснення цілого ряду комплексу заходів, що включають заходи з профрілактики та зміцнення здоров'я $[4,9]$. Середній медичний персонал, який володіє новими сестринськими технологіями, може приймати самостійні рішення, звільняючи лікаря від зайвих консультацій, викликів додому до пацієнтів із хронічними захворюваннями, тобто вивільняє час лікаря на прийом пацієнтів, яким дійсно потрібна саме його консультація [10].

На думку учасників дослідження, самостійно вирішити проблему пацієнта без жодних консультацій із лікарем у більшості випадків могли середні медичні працівники. При цьому більша половина респондентів згідна на упровадження самостійного прийому медичних сестер у центрах ПМСД. Варто вказати, що упровадження самостійного прийому пацієнтів медичною сестрою загальної практики

\section{СПИСОК ЛІТЕРАТУРИ}

1. Кабанцова А. В. Сучасний стан медсестринського процесу : огляд літератури / А. В. Кабанцова // Медсестринство. - 2012. - № 3. - С. 35-38.

2. Юристовська Н. Напрямки державного забезпечення рівноправності у доступі до медичних послуг сільського населення у процесі реформування системи охорони здоров'я / Н. Юристовська // Ефективність державного управління. - 2017. - Вип. 4 (53). - С. 121-129.

3. Абзалова Р. А. Потенциальные возможности специалистов сестринского дела в оказании первичной медико-санитарной помощи / Р. А. Абзалова, А. А. Искакова // потребує безперервної профресійної освіти середнього медичного персоналу; створення алгоритмів діяльності медичної сестри в лікувально-діагностичному процесі; відпрацювання системи взаємодії медичних сестер із лікарем загальної практики і лікарями-орахівцями поліклініки; створення власних і адаптацію вже наявних технологічних стандартів; розвиток інституту наставництва та адаптації на робочому місці серед медичних сестер; створення інфрормаційної підтримки сестринського процесу; розробки системи диореренційованої оплати праці, з метою мотивації, орієнтований на результат роботи команди «лікар-медична сестра».

\section{ВИСНОВКИ}

На думку пацієнтів, медична сестра загальної практики - це рівноправний учасник поряд із лікарем загальної практики усіх видів лікувально-просрілактичної роботи в центрі первинної медико-санітарної допомоги. Перевагами самостійного виду прийому медичними сестрами загальної практики є перерозподіл орункцій між лікарями та медичними сестрами, посилення позицій медсестринського персоналу на усіх рівнях медичного обслуговування, підвищення соціального статусу і професійної ролі медичної сестри.

Психиатрия, психотерапия наркология. Специальный выпуск. - 2014. - № 2-3(39). - C. 7-8.

4. Nursing practice in primary care and patients' experience of care / R. Borgès Da Silva, I. Brault, R. Pineault [et al.] // Journal of Primary Care and Community Health. 2018. - Vol. 9. - P. 1-7.

5. Substitution of physicians by nurses in primary care: a systematic review and meta-analysis / N. A. MartínezGonzález, S. Djalali, R. Tandjung [et al.] // BMC Health Serv. Res. - 2014. - Vol. 14. - P. 214

6. Changing nursing practice within primary health care 
innovations: the case of advanced access model / S. Abou Malham, M. Breton, N. Touati [et al.] // BMC Nurs. - 2020. - Vol.19. - P. 115.

7. Bodenheimer T. Rethinking the primary care workforce - an expanded role for nurses. / T. Bodenheimer, L. Bauer // N. Engl. J. Med. - 2016. - Vol. 375 (11). - P. 1015-1017.

8. Чернявська Л. І. Стан здоров'я студентів, проблеми та шляхи їх вирішення / Л. І. Чернявська, І. Я. Криницька, О. П. Мялюк// Медсестринство. 2017. -№ 1.C. 24-27.

\section{REFERENCES}

1. Kabantsova AV. [The current state of the nursing process (literature review)]. Medses. 2012;3: 35-8. Ukrainian.

2. Yuristovska N. [Directions of state provision of equality in access to medical services of the rural population in the process of reforming the health care system]. Efekt derzh upravl. 2017;4(53): 121-9. Ukrainian.

3. Abzalova RA, Iskakova AA. [Potential opportunities for nursing professionals in providing primary health care]. Psykh psykhoterap, narkol. Spets vyp. 2014;2-3(39): 7-8. Russian.

4. Borgès Da Silva R, Brault I, Pineault R, Chouinard MC, Prud'homme A, D'Amour D. Nursing practice in primary care and patients' experience of care. Journal of Primary Care and Community Health. 2018;9: 1-7.

5. Martínez-González NA, Djalali S, Tandjung R, Huber-Geismann F, Markun S, Wensing M, Rosemann T. Substitution of physicians by nurses in primary care: a systematic review and meta-analysis. BMC Health Serv Res. 2014;14: 214.
9. Дячук Д. Д. Реалізація профрілактичних стратегій в первинній ланці охорони здоров'я. Можливості та перспективи розвитку безперервної професійної освіти в медичній сорері / Д. Д. Дячук, Т. С. Ласиця // Інновації в медицині. - 2012. - № 9-10. - С. 39-40.

10. Task shifting of antiretroviral treatment from doctors to primary-care nurses in South Africa (STRETCH): a pragmatic, parallel, cluster randomised trial / L. Fairall, M. O. Bachmann, C. Lombard [et al.] // Lancet. - 2012. Vol. 380. - P. 889-898.

6. Abou Malham S, Breton M, Touati N, Maillet L, DuhouxA Gaboury I. Changing nursing practice within primary health care innovations: the case of advanced access model. BMC Nurs. 2020;19(1): 115.

7. Bodenheimer $T$, Bauer L. Rethinking the primary care workforce - an expanded role for nurses. N Engl J Med. 2016;375(11): 1015-7.

8. Chernyavska LI, Krynytska IYa, Myalyuk OP. [The state of health of students, problems and ways to solve them]. Medses. 2017;1: 24-7. Ukrainian.

9. Dyachuk DD, Lasitsa TS. Implementation of prevention strategies in primary care. [Opportunities and prospects for the development of continuing professional education in the medical field]. Innov v med. 2012;9-10: 39-40. Ukrainian.

10. Fairall L, Bachmann MO, Lombard C, Timmerman V, Uebel K, Zwarenstein M, Boulle A, et al. Task shifting of antiretroviral treatment from doctors to primary-care nurses in South Africa (STRETCH): a pragmatic, parallel, clusterrandomised trial. Lancet. 2012;380(9845): 889-98. 